\title{
Hydroformylation of 1-hexene with a Cobalt Catalyst in lonic Liquids: a New Efficient Approach for Generation and Recycling of the Catalyst
}

\author{
L. Magna, S. Harry, D. Proriol, L. Saussine and H. Olivier-Bourbigou \\ Institut français du pétrole, IFP-Lyon, BP 3, 69390 Vernaison - France \\ e-mail: lionel.magna@ifp.fr - stephane.harry@ifp.fr - david.prorio@ifp.fr - lucien.saussine@ifp.fr - helene.olivier-bourbigou@ifp.fr
}

\begin{abstract}
Résumé - Hydroformylation du 1-hexene en présence d'un catalyseur à base de cobalt dans un liquide ionique : Nouvelle approche pour la génération et le recyclage du catalyseur - La réaction d'hydroformylation des oléfines a été réalisée avec un système à base de cobalt en association avec des ligands de type pyridine en solution dans des liquides ioniques non aqueux. Dans ce travail, une approche originale est développée pour recycler le système catalytique sans addition de produit chimique. Pour la transformation de l'hexène-1, l'activité du système " $\left[\mathrm{Co}_{2}(\mathrm{CO})_{8}\right] /$ Pyridine (2 eq)/[BMIM] $\left[\mathrm{NTf}_{2}\right]$ " à 100 bar et $130^{\circ} \mathrm{C}$, peut atteindre $110 \mathrm{~h}^{-1}$ avec une sélectivité en aldéhydes de $87 \%$ (le rapport $\mathrm{n} /$ iso est de 1.8). Le recyclage de la phase liquide ionique, qui contient le cobalt, a été réalisé plusieurs fois sans perte d'activité ni de sélectivité.
\end{abstract}

\footnotetext{
Abstract - Hydroformylation of 1-hexene with a Cobalt Catalyst in Ionic Liquids: a New Efficient Approach for Generation and Recycling of the Catalyst - Hydroformylation of olefins has been performed with a system based on cobalt and pyridine ligands in non-aqueous ionic liquids. In this work, a new approach was developed to recycle the cobalt catalyst without the use of chemicals. For 1-hexene, activity of the " $\left[\mathrm{Co}_{2}(\mathrm{CO})_{8}\right] /$ Pyridine $(2 \mathrm{eq}) /[\mathrm{BMIM}]\left[\mathrm{NTf}_{2}\right]$ " at 100 bar and $130^{\circ} \mathrm{C}$ can reach $110 \mathrm{~h}^{-1}$ with a selectivity for aldehydes of up to $87 \%$ (linear to branched ratio being around 1.8). The recycling of the ionic liquid phase was performed several times without loss of activity or selectivity.
} 


\section{INTRODUCTION}

Hydroformylation reaction is one of the most important homogeneous transition metal catalyzed processes in industry today [1]. Several metals have been described as catalyzing this reaction, but only systems based on cobalt and rhodium are industrially applied. In the actual industrial oxo processes, the separation of the catalyst from the products and its recycling remain constant preoccupations. These points are particularly crucial when very expensive metal is used [2]. In this context, the development of the aqueous biphasic oxo process can be considered as an important breakthrough [3]. The separation is operated by decantation, which simplifies the process scheme and limits the risks of catalyst decomposition during distillation. Although the oxo Ruhrchemie/Rhône-Poulenc process presents undeniable advantages, its application remains limited to short-chain olefins (C2-C5) because of the low solubility of higher olefins in water [4]. In order to overcome this limitation, the elegant concept of biphasic catalysis for hydroformylation reaction was further extended to other media such as perfluorinated solvents, supercritical fluids and non-aqueous ionic liquids [5].

On account of their very particular properties, such as thermal and chemical stability, low vapor pressure, high and tunable solubility of olefins even with long alkyl chains, etc., ionic liquids represent an interesting alternative to substitute water in this reaction [6]. The transposition of hydroformylation in a biphasic system using ionic liquids remains, however, a big challenge; especially because of the neutral nature of the active catalytic species, e.g. $\left[\mathrm{HRh}(\mathrm{CO}) \mathrm{L}_{3}\right]$ and $\left[\mathrm{HCo}(\mathrm{CO})_{4}\right]$ or $\left[\mathrm{HCo}(\mathrm{CO})_{3} \mathrm{~L}\right]$. Partitioning of the catalyst between the organic and the ionic liquid phase is highly probable. Addition of ionic tags on ligands can make good immobilization of the catalyst possible. To date, this approach has essentially been described for rhodium catalysts [7]. Nevertheless, cobalt remains interesting for the transformation of long alkyl chain olefins as well as for internal and branched olefins, for which an isomerizing catalyst is necessary for a high conversion level. The cobalt-carbonyl complexes such as $\left[\mathrm{HCo}(\mathrm{CO})_{4}\right]$ are indeed naturally isomerizing and can reach a high conversion and convenient linear to branched ratio even starting from internal and branched olefins [8].

\section{Acronyms:}

$[$ BuMePyrr $]=N, N$-butylmethylpyrrolidinium

[EMIM] $=$ 1-ethyl-3-methylimidazolium

[BMIM] = 1-butyl-3-methylimidazolium

$\left[\mathrm{NTf}_{2}\right]=$ bistrifluoromethylsulfonimide

$[\mathrm{OTs}]=$ p-toluenesulfonate

\section{HYDROFORMYLATION OF 1-HEXENE IN IONIC LIQUIDS}

In this study, we report a new approach to performing 1-hexene hydroformylation and to recycling the cobalt catalyst using ionic liquids. In the presence of a Lewis base such as pyridine, $\left[\mathrm{Co}_{2}(\mathrm{CO})_{8}\right]$ can generate neutral or ionic species according to the $\mathrm{CO} / \mathrm{H}_{2}$ pressure and temperature conditions. Reactivity of $\left[\mathrm{Co}_{2}(\mathrm{CO})_{8}\right]$ with pyridine is widely documented [9]. Addition of pyridine to $\left[\mathrm{Co}_{2}(\mathrm{CO})_{8}\right]$ yields generally to the formation of ionic species, mainly $\left[\mathrm{Co}(\mathrm{Py})_{6}\right]^{2+}\left[\mathrm{Co}(\mathrm{CO})_{4}\right]_{2}$. In homogeneous conditions, catalytic performances of the " $\left[\mathrm{Co}_{2}(\mathrm{CO})_{8}\right] /$ Pyridine" systems are reported [10]. It has been demonstrated that the addition of pyridine to $\left[\mathrm{Co}_{2}(\mathrm{CO})_{8}\right]$ can accelerate the reaction rate and limits the formation of high boiling products, giving one more argument for interest in systems based on these associations.

\subsection{Study of the Ligand effect in [BuMePyrr][NTf $\left.{ }_{2}\right]$}

In a first series of experiments, we performed the hydroformylation of 1-hexene in $[\mathrm{BuMePyrr}]\left[\mathrm{NTf}_{2}\right]$ in the presence of Lewis bases derived from pyridine. To ensure the separation of products in a separated second phase at the end of the reaction, heptane was added to the reaction mixture. When using the $[\mathrm{BuMePyrr}]\left[\mathrm{NTf}_{2}\right]$ as ionic liquid, remarkable ligand effects are observed, as illustrated in Table 1 . With pyridine $(2 \mathrm{eq} / \mathrm{Co})$ (entry 4$)$, high conversion of 1-hexene is obtained after 1 hour. Selectivity for aldehydes is established at $87 \%$ with a linear to branched ratio around 1.8. Small amounts of alcohols, and isomerized and hydrogenated products are also observed (respectively, $<1 \%, \approx 5 \%$ and $\approx 1 \%$ ). The main side reaction produces "high boiling products" ( $\approx 6 \%)$ essentially obtained by aldehyde/alcohol condensations. In contrast to this first result, no activity at all was detected with an equivalent amount of 3,5-dimethylpyridine (entry 6) or 2,6dimethylpyridine (entry 7). The crucial role of the ligand is also demonstrated by the study of the L/Co ratio. With two equivalents of pyridine with respect to cobalt (entry 4) the activity is established at $111 \mathrm{~h}^{-1}$. When the L/Co ratio increases to 5 , no gas consumption is detected (entry 5 ) in the same operating conditions. Other ligands reported in Table 1 (entries 1-3) were also evaluated. The results obtained seem to demonstrate a correlation between the ligand basicity and the activity of the catalyst. One can assume that the more basic the ligand is, the lower the activity. A similar demonstration was carried out many years ago by R. Iwanaga for methylacrylate hydroformylation in a single homogeneous system. Selectivity for aldehydes remains quite similar for all the active systems studied (entries 1-4). 
TABLE 1

Ligand effects on hydroformylation reaction in [BuMePyrr][NTf2 $]^{\mathrm{a}}$

\begin{tabular}{|c|c|c|c|c|c|c|c|}
\hline Entry & Ligand & $\mathrm{Pk}_{\mathrm{b}}$ & $\mathrm{L} /$ Co ratio & Conv. (\%) & Ald. Sel. (\%) & n/iso Ald. & $\operatorname{TOF}^{\mathrm{b}}\left(\mathrm{h}^{-1}\right)$ \\
\hline 1 & 2,6-di ${ }^{\text {ter }}$ butylpyridine & 10.4 & 2.4 & 99.5 & 84 & 2.3 & 254 \\
\hline 2 & 2-methoxypyridine & 10.9 & 2.1 & 99.5 & 80 & 2.1 & 260 \\
\hline 3 & 3-methoxypyridine & 9.1 & 2.0 & 98 & 81 & 1.8 & 131 \\
\hline 4 & pyridine & 8.8 & 2.0 & 88 & 87 & 1.8 & 111 \\
\hline 5 & pyridine & 8.8 & 5.1 & \multicolumn{4}{|c|}{ no gas consumption } \\
\hline 6 & 3,5-dimethylpyridine & 7.9 & 2.3 & \multicolumn{4}{|c|}{ no gas consumption } \\
\hline 7 & 2,6-dimethylpyridine & 7.2 & 2.1 & \multicolumn{4}{|c|}{ no gas consumption } \\
\hline
\end{tabular}

a $\left[\mathrm{Co}_{2}(\mathrm{CO})_{8}\right](0.105 \mathrm{~g}, 0.31 \mathrm{mmol}) ;\left[\right.$ BuMePyrr] $\left[\mathrm{NTf}_{2}\right](3 \mathrm{~mL})$; heptane $(8 \mathrm{~mL}) ; 1$-hexene $(4 \mathrm{~mL}, 2.69 \mathrm{~g}, 32 \mathrm{mmol}) ; 100$ bar CO/ $\mathrm{H}_{2}(1 / 1) ; 130^{\circ} \mathrm{C}$; stirring rate: $1500 \mathrm{rpm}$; reaction time: $1 \mathrm{~h}$.

b From gas consumption at $25 \%$ conversion, expressed in mol of converted 1-hexene per mol of cobalt per hour.

\subsection{The lonic Liquid Effect}

The nature of the ionic liquid is also a key point for the catalyst activity (Table 2). In this work, six different ionic liquids were evaluated (entries 8-13). All of them are derived from 1,3-dialkylimidazolium or $N, N$-dialkylpyrrolidinium cations associated with $\mathrm{NTf}_{2}^{-}, \mathrm{PF}_{6}^{-}, \mathrm{CH}_{3} \mathrm{SO}_{3}^{-}$or $\mathrm{OTs}^{-}$anions. All catalytic tests are conducted at 100 bar and $130^{\circ} \mathrm{C}$ using a combination of $\left[\mathrm{Co}_{2}(\mathrm{CO})_{8}\right]$ with 2 equivalents of pyridine. The best results were obtained in [BMIM] $\left[\mathrm{NTf}_{2}\right]$ and $[\mathrm{BuMePyrr}]\left[\mathrm{NTf}_{2}\right]$. In contrast to these results, no activity is observed when hydroformylation is conducted in [EMIM] $\left[\mathrm{CH}_{3} \mathrm{SO}_{3}\right.$ ], [BMIM][OTs] or [EMIM][OTs]. To a lesser extent, a parasite reactivity is also observed in $[\mathrm{BMIM}]\left[\mathrm{PF}_{6}\right]$ as no recycling can be possible with this ionic liquid.

A reaction between the anion of the ionic liquid and $\left[\mathrm{Co}_{2}(\mathrm{CO})_{8}\right]$ is suspected to explain this phenomenon. At the end of the run using [EMIM][OTs], the ionic liquid phase appears with an intense blue color. Both the color and IR spectrum (large $\left[\mathrm{Co}(\mathrm{CO})_{4}\right]^{-}$band at $\left.1890 \mathrm{~cm}^{-1}\right)$ [11] of the ionic liquid phase suggest the presence of $[\mathrm{EMIM}]\left[\mathrm{Co}(\mathrm{CO})_{4}\right]$. A putative mechanism to explain this reactivity is proposed in Equation 1 for the general case of $[\mathrm{EMIM}][\mathrm{X}]$. This reactivity only takes place with the most coordinating anions and seems to correlate with the catalytic results observed. Further analyses are being conducted to clearly demonstrate the existence of this species.

$$
\begin{aligned}
& 2[\mathrm{EMIM}][\mathrm{X}]+3 / 2 \mathrm{Co}_{2} \mathrm{CO}_{8} \rightarrow 2[\mathrm{EMIM}]\left[\mathrm{Co}(\mathrm{CO})_{4}\right] \\
&+\mathrm{CoX}_{2}+4 \mathrm{CO}
\end{aligned}
$$

\subsection{The Recycling of the Catalyst}

Recycling experiments of the catalyst were performed on a representative system $\left(\mathrm{Co}_{2} \mathrm{CO}_{8} / \mathrm{Pyridine}(2 \mathrm{eq}) /[\mathrm{BMIM}]\right.$ $\left.\left[\mathrm{NTf}_{2}\right] / 100 \mathrm{bar} / 130^{\circ} \mathrm{C}\right)$. After each run, the ionic liquid is separated from the organic phase and fresh 1-hexene and

TABLE 2

\begin{tabular}{|c|c|c|c|c|c|}
\hline Entry & Ionic Liquids & Conv. $(\%)$ & Ald. Sel. (\%) & $\mathrm{n}$ /iso Ald. & $\operatorname{TOF}^{\mathrm{b}}\left(\mathrm{h}^{-1}\right)$ \\
\hline 8 & {$[$ BuMePyrr $]\left[\mathrm{NTf}_{2}\right]$} & 88 & 87 & 1.8 & 111 \\
\hline 9 & {$[\mathrm{BMIM}]\left[\mathrm{NTf}_{2}\right]$} & 90 & 87 & 1.8 & 110 \\
\hline 10 & {$[\mathrm{BMIM}]\left[\mathrm{PF}_{6}\right]$} & 66 & 91 & 1.8 & 47 \\
\hline 11 & [BMIM][OTs] & \multicolumn{4}{|c|}{ no gas consumption } \\
\hline 12 & [EMIM][OTs] & \multicolumn{4}{|c|}{ no gas consumption } \\
\hline 13 & {$[\mathrm{EMIM}]\left[\mathrm{CH}_{3} \mathrm{SO}_{3}\right]$} & \multicolumn{4}{|c|}{ no gas consumption } \\
\hline
\end{tabular}

Ionic liquid effect on hydroformylation reaction ${ }^{\mathrm{a}}$

a $\left[\mathrm{Co}_{2}(\mathrm{CO})_{8}\right](0.105 \mathrm{~g}, 0.31 \mathrm{mmol})$; Pyridine $(2 \mathrm{eq} / \mathrm{Co})$; Ionic liquid $(3 \mathrm{~mL})$; heptane $(8 \mathrm{~mL}) ; 1$-hexene $(4 \mathrm{~mL}, 2.69 \mathrm{~g}, 32 \mathrm{mmol}) ; 100 \mathrm{bar} \mathrm{CO} / \mathrm{H}_{2}(1 / 1)$; $130^{\circ} \mathrm{C}$; stirring rate: $1500 \mathrm{rpm}$; reaction time: $1 \mathrm{~h}$.

b From gas consumption at $25 \%$ conversion, expressed in mol of converted 1-hexene per mol of cobalt per hour. 

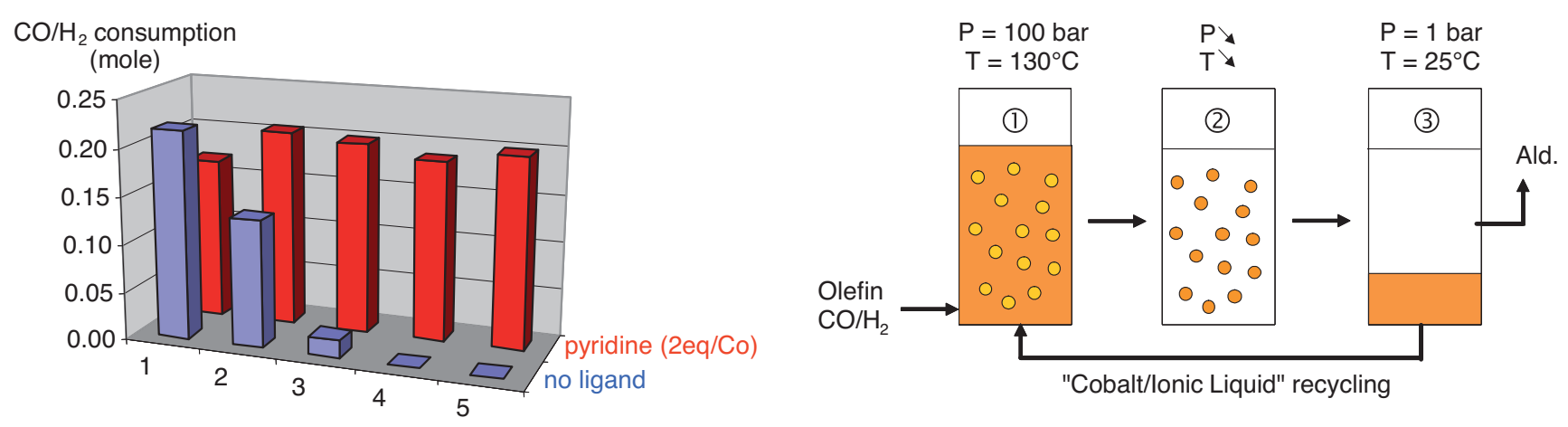

Figure 1

Recycling experiments with or without pyridine. $\left[\mathrm{Co}_{2}(\mathrm{CO})_{8}\right]$ $(0.21 \mathrm{~g}, 0.62 \mathrm{mmol})$; pyridine when used $(\mathrm{L} / \mathrm{Co}=2)$; [BMIM] $\left[\mathrm{NTf}_{2}\right](6 \mathrm{~mL})$; heptane $(30 \mathrm{~mL})$; 1-hexene $(15 \mathrm{~mL})$; 100 bar $\mathrm{CO} / \mathrm{H}_{2} ; 130^{\circ} \mathrm{C} ; 1 \mathrm{~h}$.

Scheme 1

Process scheme (1-Reaction, 2- Cobalt recovery in the ionic liquid, 3-Separation).

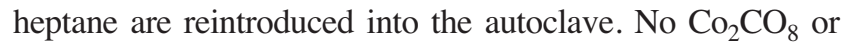
pyridine are added between each catalytic run. Slight changes in activity are observed with each cycle (Fig. 1). The same comments can be made for aldehyde selectivity (not presented here), which is established at around $80 \%( \pm 3 \%$ depending on the run). The cobalt content in the organic phase after each cycle was estimated by ICP analyses. The values are established between $100 \mathrm{ppm}$ and $150 \mathrm{ppm}$ depending on the run. In addition to these first results, another recycling experiment was performed. The system used is equivalent to the first one but without any pyridine added (Fig. 1). After $1 \mathrm{~h}$ of reaction time, syngas consumption is quite similar in both cases. However, with no ligand, the cobalt is rapidly extracted in the organic phase and cannot be recovered, making the second and third runs quite inactive with respect to the first one.

\section{DESCRIPTION OF THE RECYCLING CONCEPT}

Ionic liquids based on $\mathrm{NTf}_{2}{ }^{-}$anions have proven to be good solvents for 1-hexene hydroformylation reaction with "cobalt/pyridine" systems. In these systems, we can assume that the active species is $\left[\mathrm{HCo}(\mathrm{CO})_{4}\right]$. As in a one-phase homogeneous system, it is formed when submitted to $\mathrm{CO} / \mathrm{H}_{2}$ pressure and when the temperature is raised. Owing to its high solubility in heptane, one can anticipate that it is extracted in the upper organic phase where it operates without any mass transport limitation.

The effect of pyridine ligands, which has been correlated to their basicity, can be ascribed to the influence of the ligand on the generation of $\left[\mathrm{HCo}(\mathrm{CO})_{4}\right]$. The change in the operating conditions from $100 \mathrm{bar} \mathrm{CO} / \mathrm{H}_{2}$ and $130^{\circ} \mathrm{C}$ to atmospheric $\mathrm{CO} / \mathrm{H}_{2}$ pressure and room temperature decreases the stability of $\left[\mathrm{HCo}(\mathrm{CO})_{4}\right]$. This latter species tends to dimerize into $\left[\mathrm{Co}_{2}(\mathrm{CO})_{8}\right]$ or reacts with pyridine to form $[\mathrm{PyH}]\left[\mathrm{Co}(\mathrm{CO})_{4}\right]$ by direct acido-basic neutralization. The $\left[\mathrm{Co}_{2} \mathrm{CO}_{8}\right]$ dimer can then react with free pyridine to produce another ionic $\left[\mathrm{Co}(\mathrm{Pyr})_{6}\right]\left[\mathrm{Co}(\mathrm{CO})_{4}\right]_{2}$ species. Because of their high affinity for the ionic medium, both these ionic species are extracted and immobilized in the ionic phase. The products can be separated by decantation and the ionic liquid containing the cobalt catalyst precursors can be recycled into the reaction section (Scheme 1). The $\left[\mathrm{HCo}(\mathrm{CO})_{4}\right]$ active species can be simply regenerated, without addition of chemicals, by changing the pressure and temperature. Evidence for the existence of these species and description of the complete reaction scheme is under investigation and will be published in a future paper (high-pressure in situ IR studies).

\section{EXPERIMENTAL PART}

\subsection{General Considerations}

All reactions were carried out using standard Schlenk techniques under an atmosphere of argon. Heptane and 1-hexene were dried and deoxygenated by distillation under argon using the appropriate drying agent. Other chemicals were purchased from commercial sources and used without further purification. The syngas $\left(\mathrm{CO} / \mathrm{H}_{2}, 50 / 50\right.$, purity $\left.>99 \%\right)$ used for hydroformylation experiments was purchased from Air Liquide. ${ }^{1} \mathrm{H}$ and ${ }^{13} \mathrm{C}$ NMR spectra were recorded on a Bruker AC $300 \mathrm{MHz}$ spectrometer. The chemical shifts were measured in ppm relative to $\mathrm{CD}_{2} \mathrm{Cl}_{2}$ as internal standard. NMR solvent $\left(\mathrm{CD}_{2} \mathrm{Cl}_{2}\right)$ was purchased from "Euriso-top" and used as received. The water content of ionic liquids was determined by Karl Fischer coulometry using a "METROHM 756 KF" apparatus. The anolyte and catholyte 
were "coulomat AG" purchased from Hydranal. For the characterization of the chloride content of ionic liquids, the qualitative " $\mathrm{AgNO}_{3}$ test" was realized [12]. Melting points of solid salts were measured on a digital apparatus from Jencons.

\subsection{Hydroformylation Experiments}

A $35-\mathrm{mL}$ autoclave was charged under argon with a mixture of $\left[\mathrm{Co}_{2}(\mathrm{CO})_{8}\right](0.105 \mathrm{~g}, 0.31 \mathrm{mmol})$ and the desired amount of ligand dissolved in $3 \mathrm{~mL}$ of ionic liquid. 1-hexene (4 mL) and heptane $(8 \mathrm{~mL})$ were then added to the autoclave. Before applying reaction conditions, this mixture appears as a liquidliquid biphasic system. The pressure was raised to 40 bar and the temperature adjusted to $80^{\circ} \mathrm{C}$ for a pre-activation period of $30 \mathrm{~min}$ (no gas consumption was observed during this period). The temperature was then raised to $130^{\circ} \mathrm{C}$ and the pressure immediately adjusted to 100 bar. The reaction mixture was then stirred at $1500 \mathrm{rpm}$ for $1 \mathrm{~h}$ and the autoclave maintained at constant pressure until the end of the reaction. The reactor was then rapidly cooled down to room temperature and the pressure released to atmospheric pressure. When opening the autoclave, the reaction mixture appears as a liquid-liquid biphasic system. After decantation and separation, the composition of the organic phase was determined by GC analysis. The rate of the reaction was estimated from the syngas consumption in a calibrated buffer during reaction. Aldehyde selectivity is expressed as the weight of aldehydes formed relative to the total weight of products which include alcohols, isomerization products (2-hexene and 3-hexene), a hydrogenation product (hexane) and high boiling products. The data presented in Figure 1 were obtained from different equipment: a $100-\mathrm{mL}$ autoclave charged with $0.21 \mathrm{~g}$ $(0.62 \mathrm{mmol})$ of $\left[\mathrm{Co}_{2}(\mathrm{CO})_{8}\right], 6 \mathrm{~mL}$ of ionic liquid, $15 \mathrm{~mL}$ of 1-hexene and $30 \mathrm{~mL}$ of $\mathrm{n}$-heptane. The procedure remains identical to the previous one.

\subsection{Ionic Liquid Synthesis}

- $[\mathrm{BMIM}]\left[\mathrm{NTf}_{2}\right]$ was obtained from [BMIM][Cl] and LiNTf $_{2}$ following a classical procedure of anion exchange in $\mathrm{CH}_{2} \mathrm{Cl}_{2}$. This product was obtained as a colorless liquid with $92 \%$ yield. The water content of this ionic liquid is lower than $50 \mathrm{ppm}$ and its chloride content lower than $3.10^{-3}$ mol. $\mathrm{L}^{-1}$.

- $[\mathrm{BMIM}]\left[\mathrm{PF}_{6}\right]$ was produced from $[\mathrm{BMIM}][\mathrm{Cl}]$ and $\mathrm{NaPF}_{6}$ following the same procedure and finally obtained as a colorless liquid with $93 \%$ yield. Water content $<50 \mathrm{ppm}$. Chloride content lower than $3.10^{-3} \mathrm{~mol} \cdot \mathrm{L}^{-1}$.

- [BMIM][OTs] was obtained from [BMIM][Cl] and NaOTs as a white solid with $75 \%$ yield. Its melting point is around $73-76^{\circ} \mathrm{C}$. Water content $<50 \mathrm{ppm}$. Chloride content lower than $3 \cdot 10^{-3} \mathrm{~mol} \cdot \mathrm{L}^{-1}$.
- [BuMePyrr] $\left[\mathrm{NTf}_{2}\right](99 \%)$ was obtained from Solvionic as a light yellow liquid and used as received. Water content $<50 \mathrm{ppm}$. The chloride content is given as lower than $2 \mathrm{ppm}$.

- [EMIM][OTs] (98\%) was purchased from Solvent Innovation as an oily product $\left(\mathrm{Mp}=37^{\circ} \mathrm{C}\right)$. The chloride content is given as $441 \mathrm{ppm}$ and water content around $1300 \mathrm{ppm}$. This ionic liquid was treated under vacuum at $50^{\circ} \mathrm{C}$ for $4 \mathrm{~h}$ before use.

- $[\mathrm{EMIM}]\left[\mathrm{CH}_{3} \mathrm{SO}_{3}\right](99 \%)$ was received from Iolitec as a colorless liquid. Water content is lower than $100 \mathrm{ppm}$. Halide content $<100 \mathrm{ppm}$. This ionic liquid was treated under vacuum at $50^{\circ} \mathrm{C}$ for $4 \mathrm{~h}$ before use.

\section{CONCLUSION}

In conclusion, an original catalytic system and metal recovery concept was demonstrated for olefin hydroformylation with cobalt complexes in ionic liquids. The recycling of the " $\left[\mathrm{Co}_{2}(\mathrm{CO})_{8}\right] /$ Pyridine/ionic liquid" phase was performed up to 4 times without significant decrease in activity and selectivity. Other ligands and ionic liquid families are currently being investigated to optimize the activity and recycling efficiency of the catalytic system.

\section{REFERENCES}

1 (a) Frohning, C.D., Kohlpaintner, C.W. and Bohnen, H.-W. (2003) Carbon Monoxide and Synthesis Gas Chemistry, in Applied Homogeneous Catalysis with Organometallic Compounds, Cornils, B. and Herrmann, W.A. (eds.), WileyVCH, Weinheim, Vol. 1, pp. 31-103; (b) van Leeuwen, P.W.N.M. (ed.) (2004) Homogeneous Catalysis, Kluwer Academic Press, Dordrecht.

2 In 2005, the price of cobalt (99.8\%) quoted around $43 \mathrm{US} \$ / \mathrm{Kg}$. Important variations were observed for rhodium. In 2004, its maximum value was established around $49000 \mathrm{US} \$ / \mathrm{Kg}$ with an average around $31783 \mathrm{US} \$ / \mathrm{kg}$.

3 (a) Kuntz, E.G. (1987) CHEMTECH, 17, 570; (b) Cornils, B. and Kuntz, E.G. (1995) J. Organomet. Chem., 502, 177.

4 Herwig, J. and Fischer, R. (2000) in Rhodium Catalyzed Hydroformylation, van Leeuwen, P.W.N.M. and Claver, C. (eds.), Kluwer Academic Publishers, Dordrecht, p. 189.

5 Cornils, B., Herrmann, W.A., Horvath, I.T., Leitner, W., Mecking, S., Olivier-Bourbigou, H. and Vogt, D. (eds.), (2005) Multiphase Homogeneous Catalysis, Wiley-VCH, Weinheim, Vols. 1 and 2.

6 (a) Wasserscheid, P. and Welton, T. (2003) Ionic Liquids in Synthesis, Wiley-VCH, Weinheim; (b) Bonhote, P., Dias, A.-P., Papageorgiou, N., Kalyanasundaram, K. and Gratzel, M. (1996) Inorg. Chem., 35, 1168; (c) Olivier-Bourbigou, H. and Magna, L. (2002) J. Mol. Catal. A: Chem., 182-183, 419.

7 (a) Favre, F., Olivier-Bourbigou, H., Commereuc, D. and Saussine, L. (2001) Chem. Commun., 1360; (b) Brasse, C.C., Englert, U., Salzer, A., Waffenschmidt, H., Wasserscheid, P. (2000) Organometallics, 19, 3818; (c) Wasserscheid, P., Waffenschmidt, H., Machnitzki, P., Kottsieper, K.W. and Stelzer, O. (2001) Chem. Commun., 451; (d) Brauer, D.J., Kottsieper, K.W., Liek, C., Stelzer, O., Waffenschmidt, H. and Wasserscheid, P. (2001) J. Organomet. Chem., 630, 177; (e) 
Kottsieper, K.W., Stelzer, O. and Wasserscheid, P. (2001) J. Mol. Catal. A: Chem., 175, 285; (f) Bronger, R.P.J., Silva, S.M., Kamer, P.C.J. and van Leeuwen, P.W.N.M. (2002) Chem. Commun., 3044; (g) for complete review see Magna, L. (2005) in Multiphase Homogeneous Catalysis, Cornils, B., Herrmann, W.A., Horvath, I.T., Leitner, W., Mecking, S., OlivierBourbigou, H. and Vogt, D. (eds.), Wiley-VCH, Weinheim, Vol. 2, pp. 477-494.

8 (a) Fell, B., Rupilius, W. and Asinger, F. (1968) Tetrahedron Lett., 3261; (b) Bianchi, M., Piacenti, F., Frediani, P. and Matteoli, U. (1977) J. Organomet. Chem., 137, 361 .

9 (a) Fachinetti, G., Fochi, G. and Funaioli, T. (1986) J. Organomet. Chem., 301, 91; (b) Sisak, A. and Marko, L. (1987) J. Organomet. Chem., 330, 201; (c) Fachinetti, G., Fochi, G., Funaioli, T. and Zanazzi, P.F. (1987) Angew. Chem. Int. Edit. Engl., 26, 680; (d) Fachinetti, G., Funaioli, T. and Marcucci, M. (1988) J. Organomet. Chem, 353, 393.
10 (a) Iwanaga, R. (1962) Bull. Soc. Chem. Japan, 35, 6, 865; (b) Roos, L. and Orchin, M. (1966) J. Org. Chem., 31, 3015; (c) Moffat, A.J. (1970) J. Catal., 19, 322; (d) Matsuda, A., Shin, S., Nakayama, J.-I., Bando, K.-I. and Murta, K. (1978) Bull. Soc. Chem. Japan, 51, 10, 3016; (e) Vigranenko, Y.T., Rybakov, V.A., Fedorov, V.S., Borisov, R.B., Gavrilova, V.M. and Gvozdovskii, G.N. (1996) Petroleum Chem., 36, 1, 56; (f) Vigranenko, Y.T., Rybakov, V.A., Kashina, V.V. and Tarasov, B.P. (1996) Kinet. Catal., 37, 4, 524.

11 Brown, R.J.C., Dyson, P.J., Ellis, D.J. and Welton, T. (2001) Chem Commun., 1862-1863.

12 Thomazeau, C., Olivier-Bourbigou, H., Magna, L., Gilbert, B. and Lutz, X. (2003) J. Am. Chem. Soc., 125, 18, 5264-5265.

Final manuscript received in April 2007 